\title{
Performance Study of a Multi-Objective Mathematical Programming Modeling Approach for Energy Optimization in Building Envelopes
}

\author{
Hussain H. Alzoubi ${ }^{\text {a }}{ }^{*}$, Mustafa Z. Ali ${ }^{b}$, Yara M. Al Manaseer ${ }^{c}$ \\ ${ }^{a}$ College of Architecture and Design, Jordan University of Science and Technology, Irbid 22110, Jordan \\ ${ }^{b}$ Faculty of Information Technology, Jordan University of Science and Technology, Irbid 22110, Jordan \\ ${ }^{c}$ Faculty of Architecture and Design, Amman Al Ahliyya University, Amman 19328, Jordan
}

\begin{abstract}
Architecture is very responsive to the environmental and climatic factors which affect the built environment with unsteady state. Technology can be used to keep these factors under control by optimizing building design to fit with the surrounding environment and the energy needs. In addition, building envelopes play a major role in achieving thermal comfort for occupants and reducing energy consumption. Building envelopes energy optimization became a leading approach in the architectural research and implementation. This study hypothesizes that using solar shading devices with suitable design decisions of the fenestration affects the daylight level, solar heat gain, visual comfort, and thermal comfort for users. The main objective of this study is to examine the relationships between building envelope design and building energy efficiency through research and simulations. In addition, it explores which combinations of the design elements are the most efficient in terms of lighting and HVAC loads which gives the designers a variety of optimum design solutions to choose the architectural from. This research focuses on the implementation and effectiveness of shading devices, glass type, and window-wall ratio (WWR) in energy optimization through building envelope. The study used MATLAB software for the mathematical model simulation while Revit software was used for the model validation. The study found that south orientation for buildings associated with horizontal shading elements is the best solution in terms of cooling loads in summer. In winter, however, the optimal solution was south orientation with vertical shading elements in terms of heating loads and illuminance levels.
\end{abstract}

Keywords: Building envelope, Simulation, Energy efficiency.

\section{Introduction}

Façade is the main part of the building envelope that responds to the effects of the surrounding environment on the interior space and environment, energy performance of the building, and the satisfaction of users [1]. Facades respond to different scenarios that contradict with each other as: daylighting and heat gain, energy efficiency and view, ventilation and energy generation [2]. Researchers through time conducted several studies to organize

${ }^{*}$ Corresponding author. Tel.: +962 777296383

Fax : +962 27201038; Email: alzoubih@umich.edu

(C) 2017 International Association for Sharing Knowledge and Sustainability

DOI: $10.5383 /$ ijtee.14.01.003 "design strategies" to produce a comfortable environment taking into account the users behaviour and the surrounding environment [3].

Currently, commercial buildings in Jordan have two design approaches; building solid facades with few openings to outdoor and the other uses complete transparent facades. The first approach needs more energy consumption for providing the required lighting levels, while the other approach needs more energy to provide a good level of thermal comfort for users. Using side lit 
facades need sensitive planning and design to ensure a balance between solar heat loss and gain and effective daylight $[4,5]$.

Designing with the daylight should be careful; applying too much daylight will increase the heat gain, and consequently will increase the cooling load [6]. Therefore, it is recommended that designers choose the appropriate strategy for daylighting control with appropriate visual and thermal comfort for users, which will contribute positively to energy consumption in buildings [6].

Accordingly, finding efficient methods for daylighting requires analyzing of building orientation, location and environment, type of the glazing material, control of daylighting levels through sensors and lighting dimming devices, shading, and lighting control systems [4]. This highlights the need to find and propose "an integrated approach" to combine optimal solutions for heating and lighting simultaneously.

\section{Intelligent Facades}

Intelligent Facades can be identified as facades with elements that is adaptable to environmental conditions and users comfort $[1,2]$. Using intelligent applications in buildings contributes to achieving users comfort and minimizes the energy use. Velikov and Thun identified the goal of buildings with intelligent envelopes as the optimization of systems related to weather, energy loss/gain and users comfort, usually by "predictive models" as a base [9].

The integration of all different types of intelligent facades can participate in reducing energy consumption, improving environmental aspects and building energy performance, raising the users comfort and reducing hazards caused by the environment

Ahmed et al. divided intelligent facades into 5 types including [1]:

- Double skin façade

- Double- glazed façade

- Ventilated façade

- Kinetic façade

- Solar Façade

\subsection{Automated Dynamic Facades}

Kinetic façade is the most known type of intelligent facades which takes an important part in designing and developing facades that interact and response to environment changes [1]. Automated kinetic facades could be described as a façade with dynamic components that is adaptable to the weather conditions and users comfort [10]. Kinetic facades can adjust their shapes and forms using automated openings in response to the changing environmental conditions which include temperature, daylight, wind, etc [11]. Also Ghaffarian Hoseini et al. stated that kinetic facades respond to the environment dynamically and adaptably. In addition, kinetic façade could be considered as one of the shells under the name "Climate Adaptive Building Shells" (CABS) [12], which offer energy savings and enhancing the users comfort $[10,12]$.

\subsection{Solar Shading Devices and Daylighting}

Solar shading devices have high influence on optimizing the performance of building energy [13]. Shading devices have different advantages which include the control of the daylight levels, users view to the exterior surroundings, and a considerable reduction in solar heat gain $[1,4,13,14]$. currently, they are used with the integration of photovoltaic cells to generate electricity from incident solar energy [16]. In addition to the previous, quantitative benefits are accomplished for improving thermal and visual comfort for the building users.

Kim et al. studied the relation between the shading devices and the daylight available through the devices; they concluded that optimized design of shading devices should increase the daylight availability and control over excessive sunlight that causes overheat time duration [15]. Other researchers studied the relation of window size and shades properties to find the optimal design related to the overall performance of energy [13]. "A transient thermal comfort model" was suggested by Tzempelikos et al. to examine the relation between different glazing materials and shading devices on temperatures, daily required heating and thermal discomfort for large areas of glazing in an office building [17]. Trading off between optimal daylight and controlling of the solar heat gain was studied by Shen and Tzempelikos in office buildings, focusing on relation between different variables; properties of shading and glazing, shading control and window size [18].

\section{Methodology}

The main aim of this study is to discuss the potential of optimizing the building envelope by predicting the daylight and heat transmittance through the fenestration including different kinds of shading devices for clear sky condition. The Study focused on the external solar shading devices. It was conducted for three orientations; South, East and West, through 3-shading systems: Overhang, Horizontal louvers, and Vertical louvers.

The method used in this research is based on quantitative simulation research. A comparative analysis was done between different simulated data, which were obtained from a mathematical model written in MATLAB.

\subsection{Objective Function}

The study developed two objective functions; Daylight and Solar heat gain/loss through the façade.

The input parameters are the building location, building orientation, fenestration properties and external shading devices properties. The model can be used at any location (including latitude and longitude) within the northern hemisphere using different orientations but for 90 degrees quadrilateral shapes (squares and rectangles). 
The optimization approach selected for this study is the "Nested loop" approach, and an algorithm was developed to give a set of cases composed of different design variables that optimize the energy related to the envelope. These results help the designers with the decision-making through the design process.

\subsection{Design Variables}

A set of variables were selected to be studied which directly affect the solution to be optimized. These variables include Building Orientation, Window-to-Wall (WWR) ratio, Glass type and the width of the external shading devices as shown in Table 1.

Table 1: Variables of optimization

\begin{tabular}{|c|l|l|}
\hline Number & \multicolumn{1}{|c|}{ Variable type } & Type of value \\
\hline \hline 3 & $\begin{array}{l}\text { Facades orientation; South, } \\
\text { East and West }\end{array}$ & discrete values \\
\hline 5 & $\begin{array}{l}\text { Window-to-Wall ratios } \\
\text { (WWR) }\end{array}$ & discrete values \\
\hline 4 & Types of glazing & discrete values \\
\hline 4 & Shading devices properties & discrete values \\
\hline
\end{tabular}

\subsection{Optimization Procedure}

An algorithm was developed depending on the calculation equations displayed in the next section, and implemented by a written code using Matlab program and java programming language. The code studied all the probabilities resulting from combining different design variables, giving results of the solar heat gain and daylighting. In order to study different variables that affect the functionality of the building envelope, the following steps were performed and visualized (See Fig. 1):
1. Possible Combinations
2. Calculation of daylight
3. Calculation of solar heat gain
4. Finding the best results from all possible combinations.

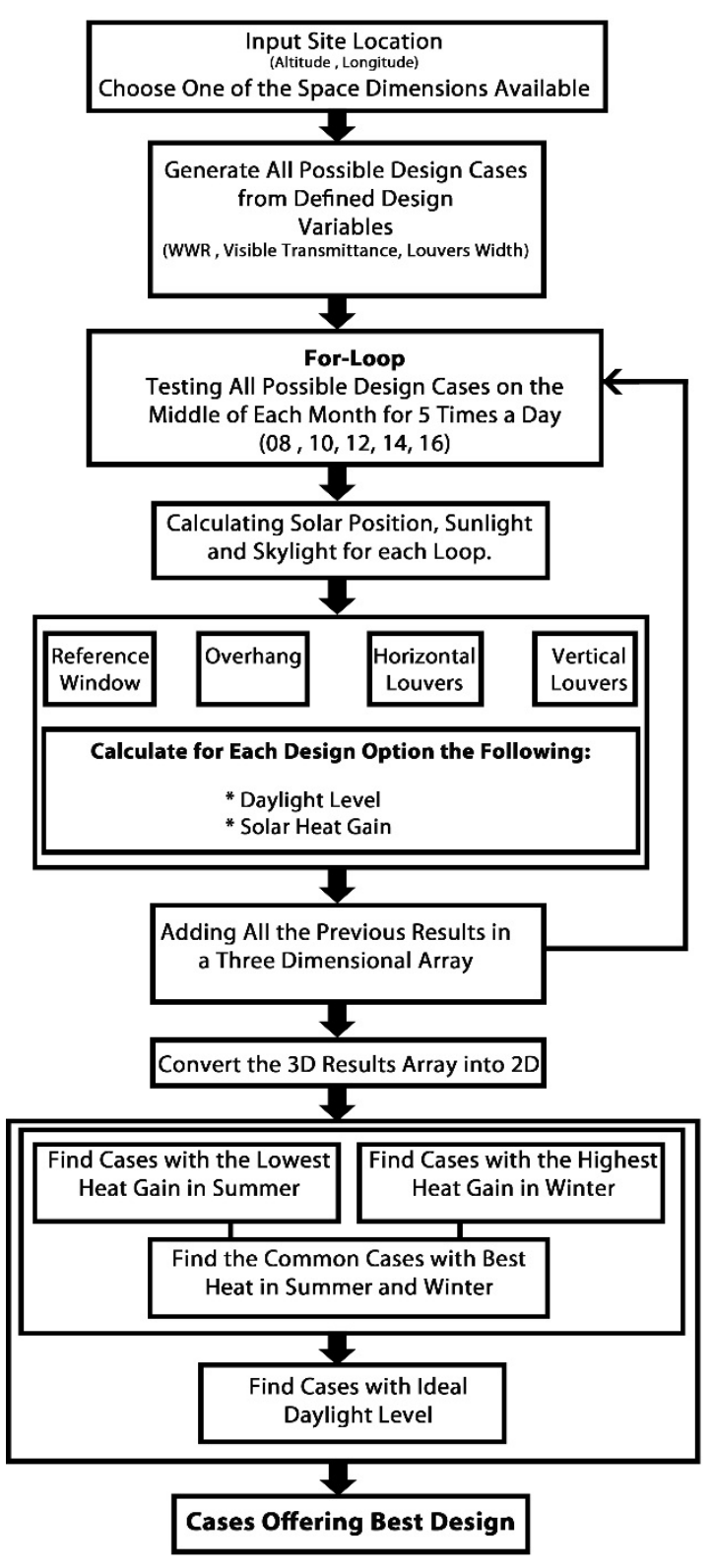

Fig.1: Methodology Flow Chart

\section{Mathematical Model}

\subsection{Louvers Geometry and cut-off angle}

The "cut-off" angle is defined as the minimum angle of the louver that could be positioned to keep blocking the direct solar radiation [22]. Fig. 2 shows a side profile for two parallel horizontal louvers in the "cut-off" angle position with respect to the sun. Equation (1) shows the relation between the sun angle and the louvers rotation angle, while Fig. 3 shows the horizontal louvers cut-off angle as a function of profile angle and louvers type. 


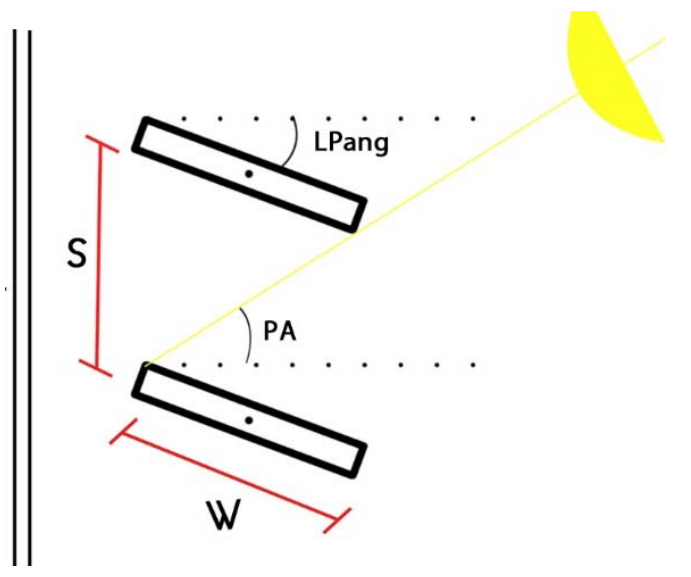

Fig. 2: A side profile for two parallel horizontal louvers in the "cut-off" angle position with respect to the sun

$$
\text { LPang }=\arcsin \left(\frac{(S * \cos P A)}{W}\right)-P A
$$

where LPang is Louver plain Angle which is considered the cutoff angle (radians), $\mathrm{S}$ is the spacing between two louvers (meters), $\mathrm{PA}$ is the profile angle (radians), and $\mathrm{W}$ is the width of the louver (meters).

The minus values of the cut-off angles means that the rotation of the louver is above the horizontal level. But this will cause an overheating through summer with the possibility of creating an unsuitable glare $[14,23]$, so it was studied only for high profile angles to keep the cut-of angle equals zero.

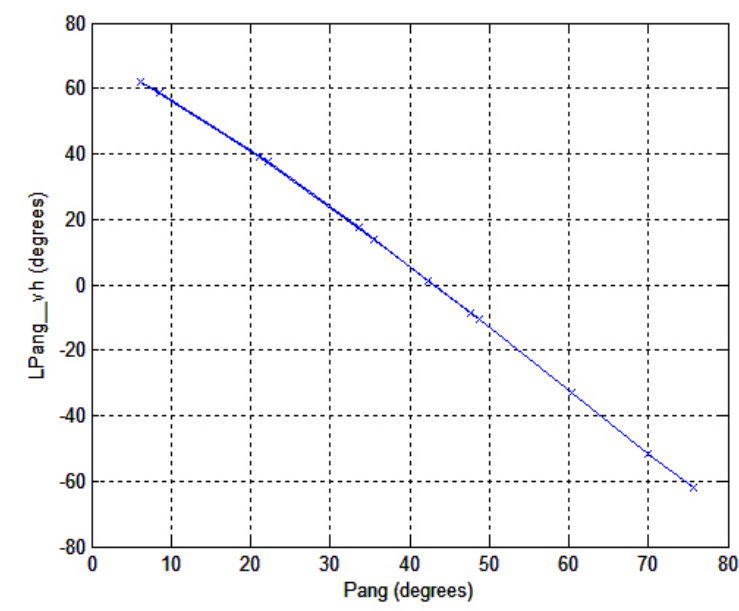

Fig. 3: Horizontal Louvers cut-off angle as a function of profile angle

\subsection{Solar Geometry}

The position of the sun is the main factor affecting the louver control angle; in addition, the sky illuminance that is predicted is dependent on the solar position [21]. The calculations of the sky and solar illuminances are site dependent these are presented by the geographical location latitude and longitude [19]. According to the IES lighting handbook, there are three categories of sky conditions; clear, partly cloudy and overcast sky [19]. In this study clear sky model was chosen; because it is the most common type of sky for the Jordan environment, in addition, it is considered the less category with a reflected skylight which means designing with the direct sunlight with minimum skylight. Daylight was calculated and quantified by the symbol E; Illuminance, which is defined as "the luminous flux incident on a surface per unit area" [6]. Illuminance measuring unit is Lux (lumen $/ \mathrm{m}^{2}$ ). It was computed at the height of the window sill, related to each window-to-wall ratio (WWR) separately, at the center of the window.

\subsection{Objective Functions Mathematical model}

\subsubsection{Daylight}

The equation used for calculating the daylight between the horizontal louvers was developed based on the clear sky daylight calculations [19] and Radiosity Theory [20, 21], shown in Fig. 4 and equation (2).

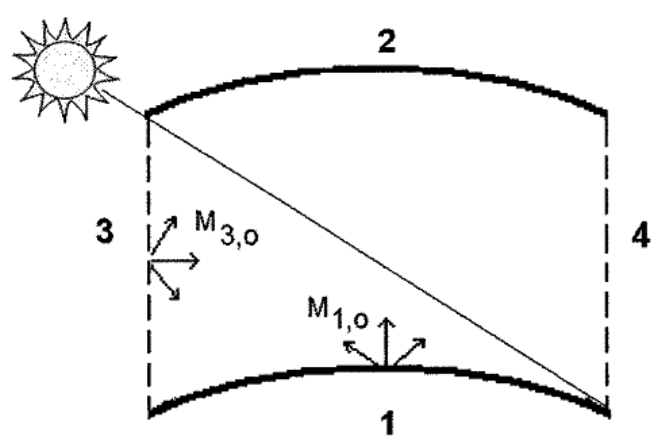

Fig. 4: Movable horizontal Louvers analyzed by Radiosity Theory [21]

$M i=M i, o+\rho i \sum_{j} M j . F j$

Where, $M_{i}$ is the final daylight available from surface $i$ (lux), $M_{i, o}$ is the initial illuminance exiting from the louver surface (lux), $\rho_{i}$ is the reflectance of surface $i, M_{j}$ is the final daylight available from surface $j$ (lux), and $\mathrm{F}_{\mathrm{j}-\mathrm{i}}$ is the view factor between surfaces $j$ and $i$.

\subsubsection{Heat Gain}

Equation (3) is the equation used to calculate solar heat gain and compare between the cases as follows:

$Q g v h=(U . A . \Delta \mathrm{T})+\frac{\text { Ash } . \text { Shgf } . \text { Lver }}{107}+0.44(A-$

Ash).Shgf.( $\left.\frac{\text { Lver }}{107}\right)$ (3)

Where, $Q g_{v h}$ is Solar Heat gain through louvered window (Watt), $U$ is the equivalence heat transfer coefficient value $\left(\mathrm{W} / \mathrm{m}^{2} . \mathrm{K}\right), A$ is 
the Window Area $\left(\mathrm{m}^{2}\right)$, and $A_{\mathrm{sh}}$ is the unshaded area of the window with louvers $\left(\mathrm{m}^{2}\right), S_{h g f}$ is the solar heat gain factor for window glass, $L_{v e r}$ is the solar illuminance on a vertical surface (lux), and $\Delta \mathrm{T}$ is the temperature difference between the outside and inside of a building (Kelvin).

\section{Experimental Results and Model Validation}

\subsection{Reference Case Study}

A reference room with $9 \mathrm{~m}$ width exposed to the outside, $12 \mathrm{~m}$ depth and $3.65 \mathrm{~m}$ height was used as a case study for the computational model as shown in Fig.5. In this section the heat gain and daylight available through the reference room without any shading devices are displayed and compared with different design variables.

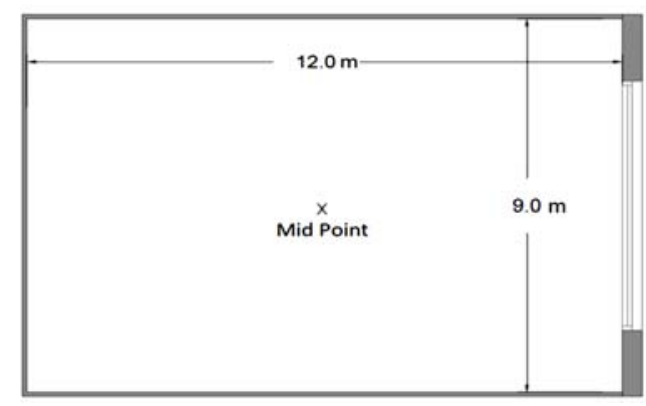

Fig. 5: A plan for the room with dimensions of ( $9 \mathrm{~m} \times 12 \mathrm{~m})$.

The program tested 80 cases to check and provide the optimal scenarios for the cases of the test room design. Based on the criteria of this study, only 9 cases were found to be optimal. Table 2 . shows these case numbers and variables that give the best design for best performance for the south façade.

Table 2: Best design cases that optimize South Façade performance of the simulated space

\begin{tabular}{|c|c|c|c|c|c|c|}
\hline $\begin{array}{c}\text { Case } \\
\text { No }\end{array}$ & $\begin{array}{c}\text { Louver } \\
\text { Width } \\
\mathbf{( m )}\end{array}$ & $\begin{array}{c}\text { Horz } \\
\text { Dist } \\
\mathbf{( m )}\end{array}$ & $\begin{array}{c}\text { Vert } \\
\text { Dist } \\
\mathbf{( m )}\end{array}$ & $\begin{array}{c}\text { WWR } \\
\mathbf{( \% )}\end{array}$ & $\begin{array}{c}\text { Visible } \\
\text { Trans. } \\
\mathbf{( \% )}\end{array}$ & $\begin{array}{c}\text { SHGF } \\
\mathbf{( \% )}\end{array}$ \\
\hline \hline 13 & 0.20 & 0.19 & 0.20 & 0.85 & 0.88 & 0.74 \\
\hline 14 & 0.20 & 0.19 & 0.20 & 0.85 & 0.78 & 0.63 \\
\hline 15 & 0.20 & 0.19 & 0.20 & 0.85 & 0.27 & 0.27 \\
\hline 16 & 0.20 & 0.19 & 0.20 & 0.85 & 0.73 & 0.55 \\
\hline 19 & 0.20 & 0.19 & 0.20 & 1.00 & 0.27 & 0.27 \\
\hline 39 & 0.35 & 0.33 & 0.35 & 1.00 & 0.27 & 0.27 \\
\hline 59 & 0.50 & 0.47 & 0.50 & 1.00 & 0.27 & 0.27 \\
\hline 76 & 0.65 & 0.61 & 0.65 & 0.85 & 0.73 & 0.55 \\
\hline 79 & 0.65 & 0.61 & 0.65 & 1.00 & 0.27 & 0.27 \\
\hline
\end{tabular}

As was shown in table 2, most of the optimized design results have been concentrated with the use of double bronze reflective glass with $\mathrm{SHGF}=0.27$ and visible transmittance $=0.27$. Also it is noted that the results have a high window to wall ratio. It ranges between $85 \%$ and $100 \%$ in relation to the used type of the glass. Table 3, on the other hand, shows the cases numbers and variables that gives the best design for the East/West façades.

Table 3: Best design cases that optimize East/West Façade performance of the simulated space

\begin{tabular}{|c|c|c|c|c|c|c|}
\hline $\begin{array}{c}\text { Case } \\
\text { No }\end{array}$ & $\begin{array}{c}\text { Louv } \\
\text { Wid. } \\
\mathbf{( m )}\end{array}$ & $\begin{array}{c}\text { Horz } \\
\text { Dist } \\
\mathbf{( m )}\end{array}$ & $\begin{array}{c}\text { Vert } \\
\text { Dist } \\
\mathbf{( m )}\end{array}$ & $\begin{array}{c}\text { WWR } \\
\mathbf{( \% )}\end{array}$ & $\begin{array}{c}\text { Visible } \\
\text { Trans. } \\
\mathbf{( \% )}\end{array}$ & $\begin{array}{c}\text { SHGF } \\
\mathbf{( \% )}\end{array}$ \\
\hline \hline 13 & 0.20 & 0.19 & 0.20 & 0.85 & 0.88 & 0.74 \\
\hline 14 & 0.20 & 0.19 & 0.20 & 0.85 & 0.78 & 0.63 \\
\hline 15 & 0.20 & 0.19 & 0.20 & 0.85 & 0.27 & 0.27 \\
\hline 19 & 0.20 & 0.19 & 0.20 & 1.00 & 0.27 & 0.27 \\
\hline 35 & 0.35 & 0.33 & 0.35 & 0.85 & 0.27 & 0.27 \\
\hline 39 & 0.35 & 0.33 & 0.35 & 1.00 & 0.27 & 0.27 \\
\hline 55 & 0.50 & 0.47 & 0.50 & 0.85 & 0.27 & 0.27 \\
\hline 59 & 0.50 & 0.47 & 0.50 & 1.00 & 0.27 & 0.27 \\
\hline 75 & 0.65 & 0.61 & 0.65 & 0.85 & 0.73 & 0.55 \\
\hline 79 & 0.65 & 0.61 & 0.65 & 1.00 & 0.27 & 0.27 \\
\hline
\end{tabular}

The results are very similar to these obtained by the south façade design. Therefore, it can help to use the same design variables in the architectural design with the difference in the daylight and heat gain.

\subsection{South Façade results}

\subsubsection{Heat Gain}

Heat gain is analysed to study the effect of using shading devices on solar heat gain passing through building envelope. The results lead to find the best design scenarios to achieve minimum heat gain, or in accordance minimum heat loss. Table 4 shows the values representing average heat gain of south façade for the studied space. It can be recognized that shading devices have a significant effect on reducing solar heat gain through glazing in summer. During winter buildings need the maximum possible heat gain, accordingly the angle of rotation was used to control the glare while allowing the entrance of solar energy. 
Table 4: Average Heat Gain of South façade

\begin{tabular}{|c|c|c|c|c|c|c|c|c|}
\hline \multirow{2}{*}{$\begin{array}{c}\text { Ca } \\
\text { se } \\
\#\end{array}$} & \multicolumn{2}{|c|}{ Reference } & \multicolumn{2}{|c|}{ Reference } & \multicolumn{2}{c|}{ Horizontal } & \multicolumn{2}{c|}{ Vertical } \\
\cline { 2 - 9 } & W & S & W & S & W & S & W \\
\hline \hline 13 & 12.3 & 7.88 & 5.85 & 2.49 & 5.70 & 3.14 & 2.77 & 3.45 \\
\hline 14 & 10.3 & 6.88 & 4.76 & 2.25 & 4.56 & 2.75 & 1.99 & 3.02 \\
\hline 15 & 4.61 & 2.72 & 2.21 & 0.72 & 2.09 & 0.91 & 0.97 & 1.03 \\
\hline 16 & 8.97 & 6.04 & 4.15 & 2.00 & 4.00 & 2.46 & 1.78 & 2.69 \\
\hline 19 & 5.42 & 3.20 & 2.59 & 0.85 & 2.46 & 1.08 & 1.14 & 1.21 \\
\hline 39 & 5.42 & 3.20 & 2.59 & 0.85 & 2.46 & 1.08 & 1.14 & 1.54 \\
\hline 59 & 5.42 & 3.20 & 2.59 & 0.85 & 2.46 & 1.08 & 1.14 & 1.41 \\
\hline 76 & 8.97 & 6.04 & 4.15 & 2.00 & 4.00 & 2.46 & 1.78 & 2.98 \\
\hline 79 & 5.42 & 3.20 & 2.59 & 0.85 & 2.46 & 1.08 & 1.14 & 1.39 \\
\hline
\end{tabular}

An illustration for all best cases of design, giving the amount of heat gain for the four types of shading for each case is shown in Fig.6. The figure shows decrease in the heat gain between the reference window (without shading) and the other shaded windows. The results of the movable overhang and the movable horizontal louvers in summer are approximately the same. While the heat gain in winter through the horizontal louvers is higher than that of the overhang case. The heat gain is minimal for the movable vertical shading devices compared to other types of shading.

\subsubsection{Daylighting Results}

The results lead to find the best design scenarios to achieve maximum daylighting. Table 5 . shows the values that represent average daylight of south façade in the studied space. It can be noticed that the shading devices reduce the daylight gained through glazing. Using automated shading devices helped in giving higher amount of daylight while it is still blocking direct sunlight.

Table 5: Average Daylight levels of South Façade (lux)

\begin{tabular}{|c|c|c|c|c|}
\hline \multirow{2}{*}{$\begin{array}{c}\text { Case } \\
\#\end{array}$} & \multicolumn{4}{|c|}{ Average Annual Daylighting (lux) } \\
\cline { 2 - 5 } & Reference & Reference & Horizontal & Vertical \\
\hline \hline 13 & 658.91 & 457.49 & 277.81 & 196.62 \\
\hline 14 & 584.03 & 405.50 & 469.06 & 343.32 \\
\hline 15 & 202.17 & 140.37 & 672.70 & 637.75 \\
\hline 16 & 546.60 & 379.51 & 549.49 & 409.62 \\
\hline 19 & 237.84 & 165.14 & 791.42 & 750.29 \\
\hline 39 & 237.84 & 165.14 & 452.24 & 402.82 \\
\hline 59 & 237.84 & 165.14 & 316.57 & 296.51 \\
\hline 76 & 546.60 & 379.51 & 169.07 & 133.06 \\
\hline 79 & 237.84 & 165.14 & 243.51 & 244.42 \\
\hline
\end{tabular}

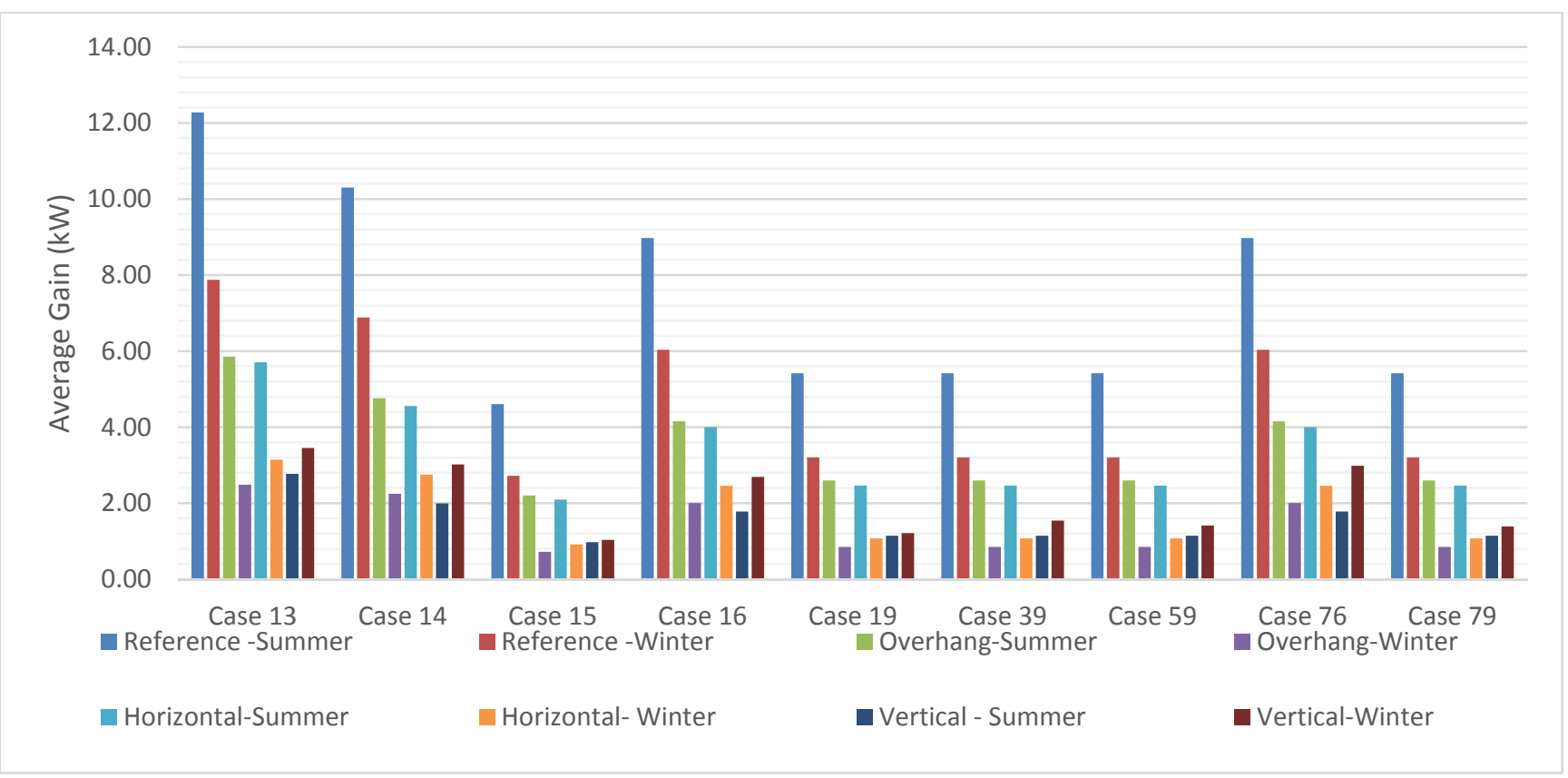

Fig. 6: Comparison between Average Heat Gain for the best cases of design 
Fig. 7 depicts an illustration for all best cases of design, giving the amount of average daylight for the four types of shading for each case. The most recognized result shown in the figure is that movable horizontal and vertical louvers offer better illuminance through the year than the overhang. This result is the cause of the indirect illuminance delivered from the reflected lighting between louvers. In addition, the results confirm that the horizontal louvers is better for illuminance than the vertical louvers in the case of the south orientation.

\subsection{East Façade Results}

The same steps of the south façade are done to show the results of the east façade.

The solar heat gain for the east facade is represented in Table 6 using the unit Kilo-Watt. Illustration for all best cases of design, giving the amount of heat gain for the four types of shading for each case (East facade), is shown in Fig. 8. The figure also shows decrease in the heat gain between the reference window (without shading) and the other shaded windows. The results of the movable horizontal and vertical louvers in summer and winter are approximately the same.

Table 6: Average Rate of Solar Heat Gain for East façade (kw)

\begin{tabular}{|c|c|c|c|c|c|c|c|c|}
\hline \multirow{2}{*}{$\begin{array}{c}\text { Ca } \\
\text { se } \\
\#\end{array}$} & \multicolumn{2}{|c|}{ Ref } & \multicolumn{2}{c|}{ Hang } & \multicolumn{2}{c|}{ Hor } & \multicolumn{2}{c|}{ Ver } \\
\cline { 2 - 9 } & S & W & S & W & S & W & S & W \\
\hline \hline 13 & 9.02 & 6.46 & 5.28 & 2.23 & 4.29 & 4.02 & 4.2 & 4.22 \\
\hline 14 & 7.53 & 5.68 & 4.21 & 1.99 & 3.39 & 3.54 & 3.3 & 3.72 \\
\hline 15 & 3.42 & 2.21 & 1.95 & 0.60 & 1.61 & 1.27 & 1.6 & 1.35 \\
\hline 19 & 4.02 & 2.60 & 2.30 & 0.71 & 1.89 & 1.50 & 1.9 & 1.59 \\
\hline 35 & 3.42 & 2.21 & 1.95 & 0.60 & 1.61 & 1.27 & 1.6 & 1.40 \\
\hline 39 & 4.02 & 2.60 & 2.30 & 0.71 & 1.89 & 1.50 & 1.9 & 1.65 \\
\hline 55 & 3.42 & 2.21 & 1.95 & 0.60 & 1.61 & 1.27 & 1.6 & 1.31 \\
\hline 59 & 4.02 & 2.60 & 2.30 & 0.71 & 1.89 & 1.50 & 1.9 & 1.55 \\
\hline 76 & 3.42 & 2.21 & 1.95 & 0.60 & 1.61 & 1.27 & 1.6 & 1.32 \\
\hline 79 & 4.02 & 2.60 & 2.30 & 0.71 & 1.89 & 1.50 & 1.9 & 1.55 \\
\hline
\end{tabular}

Table 7 shows the average daylight illuminance for the best scenarios found by the program. An illustration for all best cases of design, giving the amount of average daylight levels for the four types of shading for each case is shown in Fig. 9. The most recognized result is that movable vertical louvers offer better illuminance through the year than the other shading devices. This is attributed to the indirect illuminance delivered from the reflected lighting between louvers.

Table 7: Average Daylight levels for East Façade (lux)

\begin{tabular}{|c|c|c|c|c|}
\hline \multirow{2}{*}{$\begin{array}{c}\text { Case } \\
\text { \# }\end{array}$} & \multicolumn{4}{|c|}{ Average Annual Daylighting (lux) } \\
\cline { 2 - 5 } & Ref. & Hang & Hor & Ver \\
\hline \hline 13 & 507.02 & 268.24 & 359.17 & 342.30 \\
\hline 14 & 449.40 & 237.76 & 613.09 & 593.85 \\
\hline 15 & 155.56 & 82.30 & 959.91 & 1068.83 \\
\hline 19 & 183.01 & 96.82 & 1129.31 & 1257.45 \\
\hline 35 & 155.56 & 82.30 & 548.52 & 623.68 \\
\hline 39 & 183.01 & 96.82 & 645.32 & 733.75 \\
\hline 55 & 155.56 & 82.30 & 383.97 & 471.01 \\
\hline 59 & 183.01 & 96.82 & 451.72 & 554.13 \\
\hline 76 & 155.56 & 82.30 & 295.36 & 376.84 \\
\hline 79 & 183.01 & 96.82 & 347.48 & 443.34 \\
\hline
\end{tabular}

\subsection{Illuminance Validation}

A proposed case study based on common commercial buildings spaces in Jordan is presented to validate the studied methodology. The dimensions of the space of the case study are: $9 \mathrm{~m}$ width by 12 length by 3.65 height. The Revit daylighting analyses are shown in Fig.10. The space orientation is parallel to East-West axis, window-to-wall ratio is $100 \%$, and the type of glazing is reflective double-pane glazing with visible transmittance percentage of $27 \%$.

The validation results was done by using Autodesk Revit daylight simulation. The results of illuminance measured in Revit, shown in Fig. 11. Then the results by revit were compared with the model illumination. The comparison between the two results is shown in figure 11 . The validation showed that there are little differences between the model illuminance and the revit simulation. 


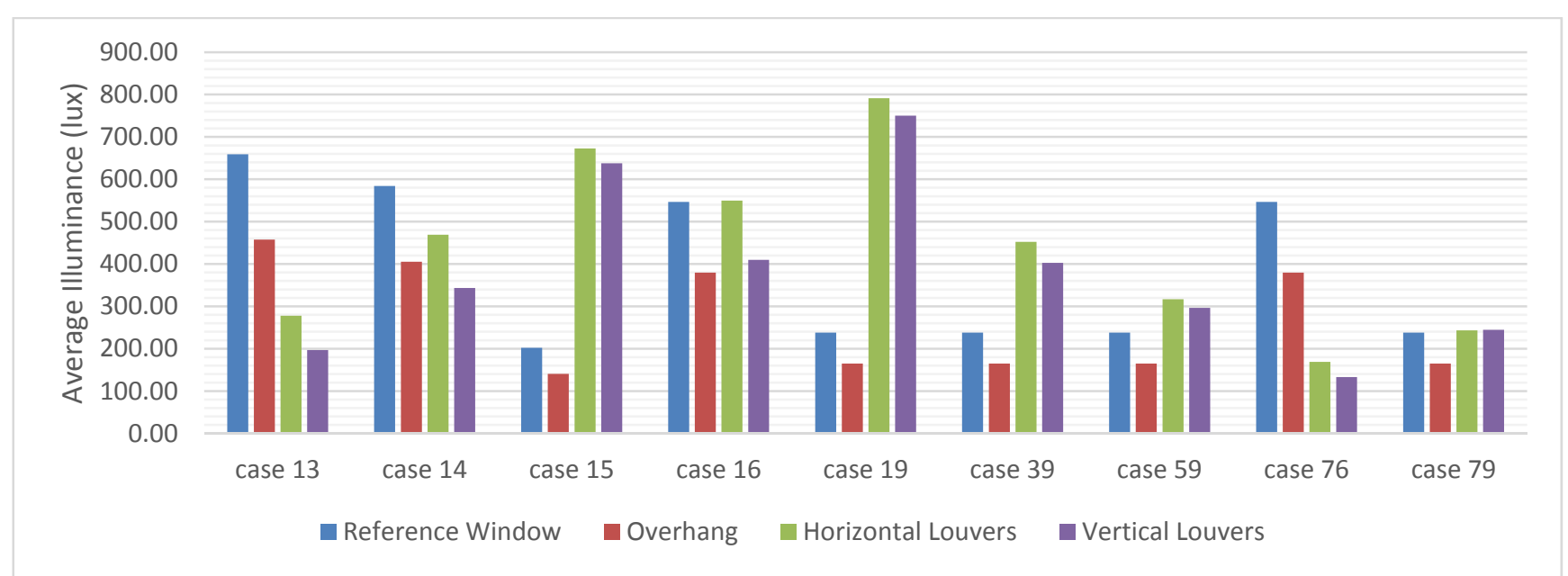

Fig. 7: Comparison between Average Daylight level of the best cases of design (South)

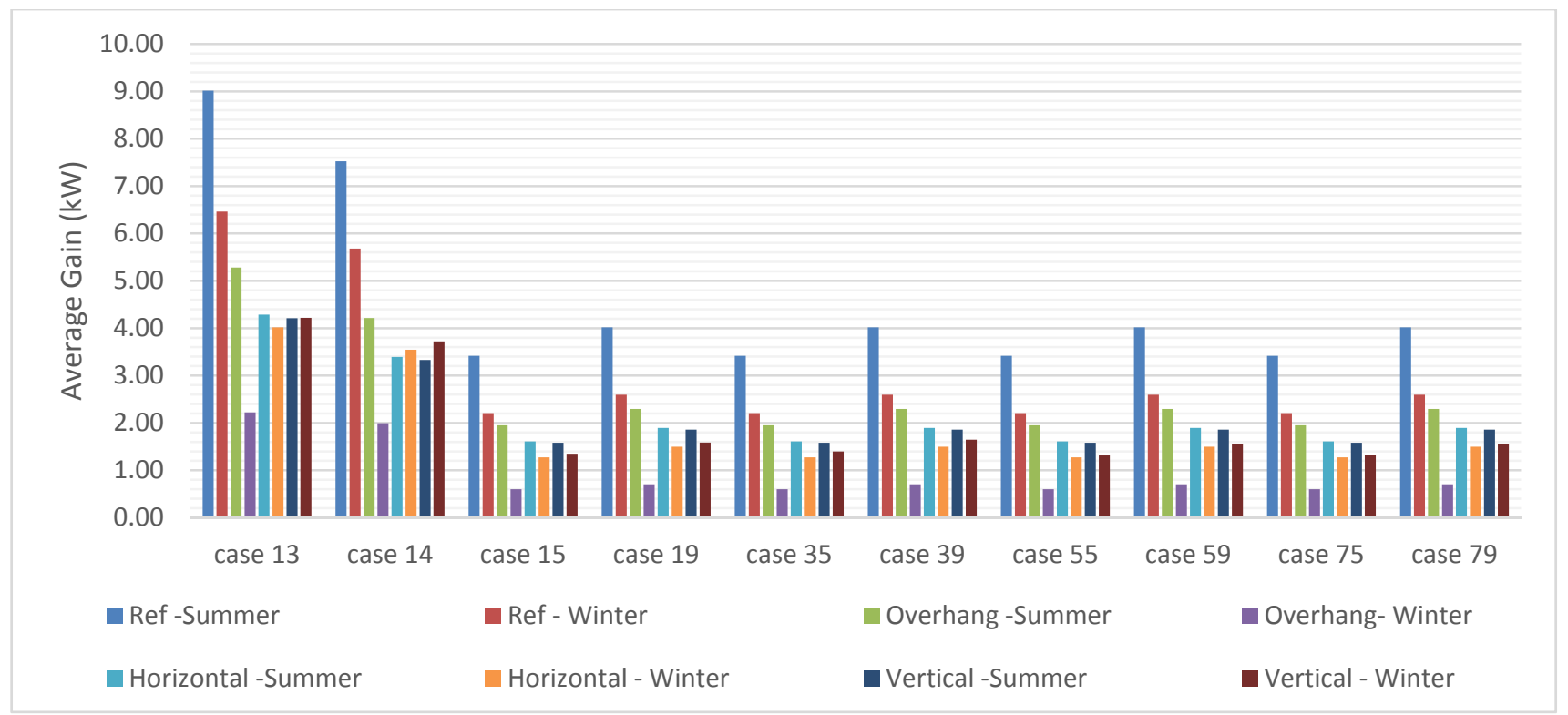

Fig. 8: Comparison between Average Heat Gain of the best cases of design (East)

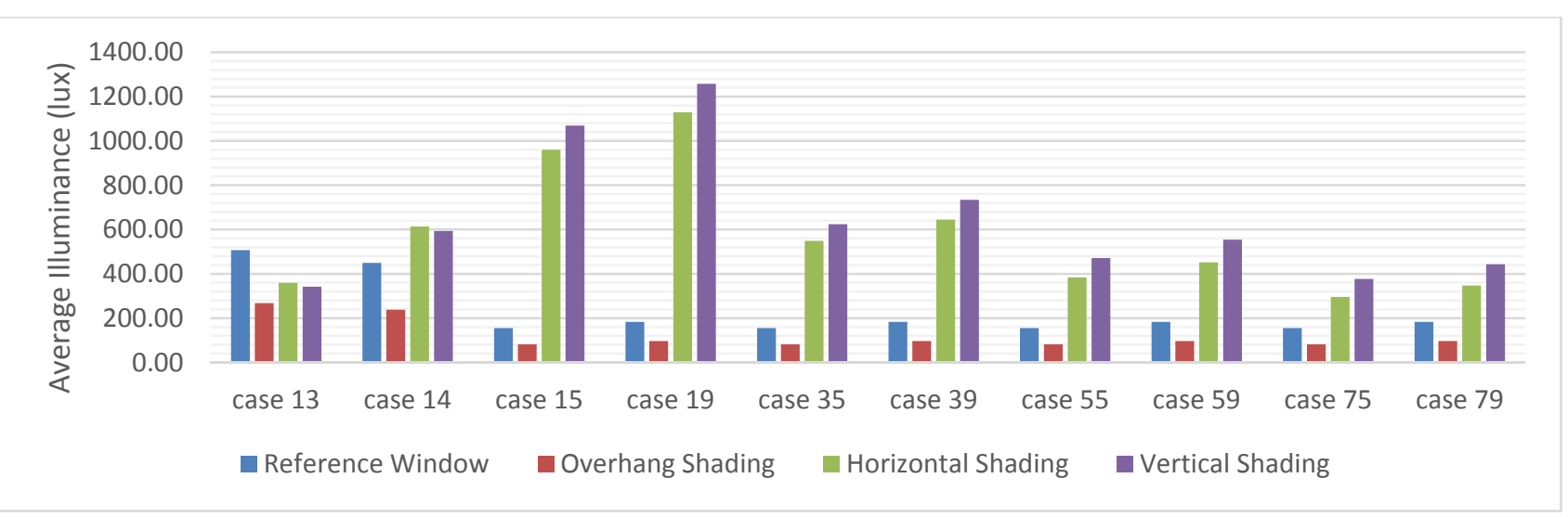

Fig. 9: Comparison between Average Daylight levels of the best cases of design (East) 


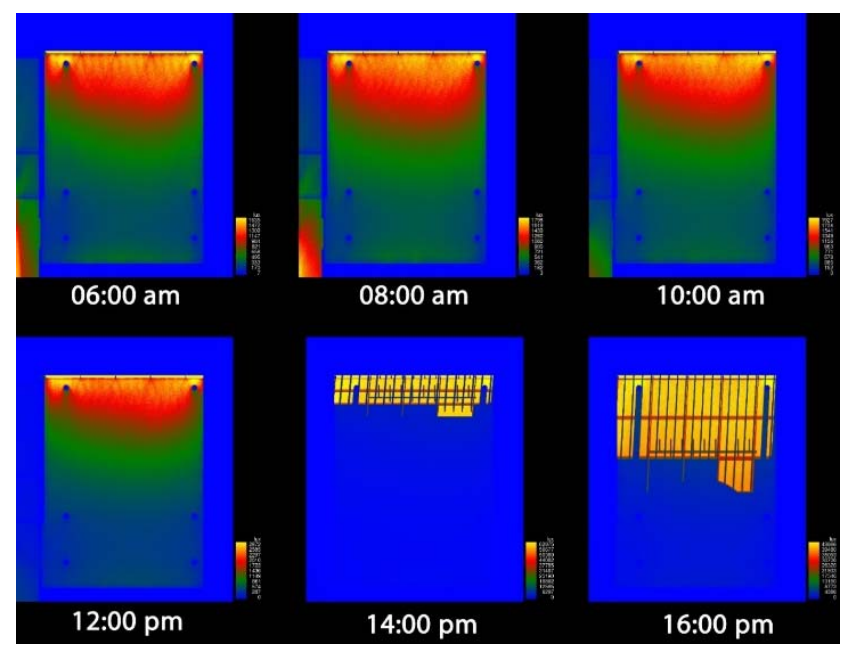

Fig. 10: Revit Daylighting modelling for different hours of the day

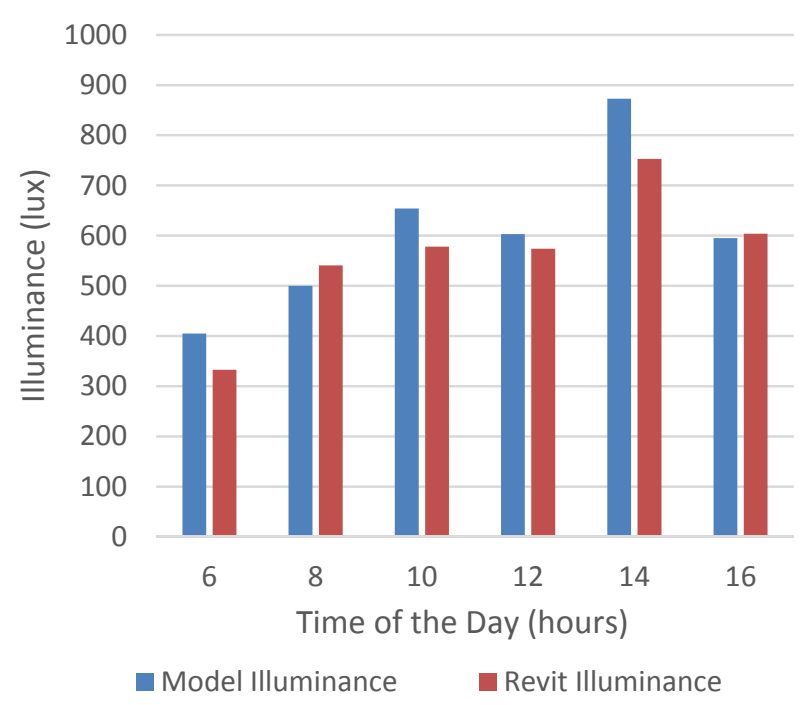

Fig. 11: Comparison between the base model and Revit analyses

\section{Recommendations}

Four strategies of control were studied and analysed for the three facades: South, West and East. These strategies are: Reference window (no shading device), movable overhang, movable horizontal louvers and movable vertical louvers. Computer simulation was conducted through mathematical model that was developed in MATLAB to simulate daylight and solar heat gain. The main independent variables were window-to-wall ratio, dimensions of louvers (overhang, horizontal and vertical) and type of glass. The results indicated that using solar shading devices affects solar heat gain and daylight levels in spaces. Solar shading devices play a major role in decreasing the amount of solar heat gain and controlling the daylight which prevents glare in spaces. This offers the occupants a good level of thermal and visual comfort in architectural spaces. It is also found that using shading devices increases energy consumption for heating and lighting during winter. The study shows that using movable shading devices with best combination of design elements such as WWR, louvers types and glass type is the best and optimal solution for daylighting and solar heat gain. However, designers can find the possible optimal solution for any specific location and space by:

- Using the programmed model directly

- Using the illustrations that can be computed through the programmed model

\subsection{How This Research Can Be Deployed in Design Decision}

Designers can refer to the desired case of design using the computer program by:

- Finding the required illuminance for the function of the space.

- Deciding the shading element preferred from the aesthetic aspect from the stand point of the designer and/or client.

- If there is a specified glazing type or color, this will minimize the number of design cases available, which will limit the options of the design decisions.

- Window to wall ratio (WWR) has a main contribution to the best design case; the results show that best cases with the highest amounts of window to wall ratios available.

\subsection{Conclusions}

Shading devices affect the performance of the building envelope, and eventually affect the energy consumption in buildings. It was found that there is no preference to the best cases of design for the three orientations, which will be beneficial to the design of buildings. Best design solutions always give cases with the highest amounts of window to wall ratio available. Generally, the results of the study agree with previous studies. The addition of shading devices controls the solar radiation, which will decrease the cooling loads during hot weather, and control the daylight level. In this study, overhang elements have the best performance in daylighting for south facades in Jordan. The second best performance is for horizontal louvers. For the west and east facades, vertical louvers are the best then the horizontal louvers. Overhang is the worst in performance for both facades west and east. The study and the computer program give a set of suitable solutions to be used in the design. Designers can get different options to maintain the aesthetics of architecture. Movable shading devices increase daylighting of the interior space, in few cases more than the normal window. This is attributed to two reasons; the adaptability of the rotation angle of the shading devices, and the reflectance of daylight that occurs between the parallel louvers with a highly reflective material.

\section{Acknowledgments}

The authors wish to thank Jordan University of Science and Technology for supporting and facilitating the work on this research. 


\section{References}

[1] Ahmed, M.M.S., Abel-Rahman, A.K. \& Ali, A.H.H. (2015). Development of Intelligent Façade Based on Outdoor Environment and Indoor Thermal Comfort. Procedia Technology, 19, 742-749.

[2] Ochoa, C., Capeluto, I. Intelligent facades in hot climates: energy and comfort strategies for successful application, (2008). 25th Conference on Passive and Low Energy Architecture, Dublin.

[3] Frontczak M, Wargocki P. Literature survey on how different factors influence human comfort in indoor environments. Building and Environment. 2011; 46(4):922-937

[4] Colaco , S.G. et al. (2008). Prospective Techniques of Effective Daylight Harvesting in Commercial Buildings by Employing Window Glazing, Dynamic Shading Devices and Dimming Control — A Literature Review. Building Simulation, 1(4), 279-289.

[5] Tzempelikos, A. \& Athienitis, A.K. (2007). The impact of shading design and control on building cooling and lighting demand. Solar Energy, 81(3), 369-382.

[6] Aste, N., Adhikari, R.S. \& Pero, C. Del. (2012). An algorithm for designing dynamic solar shading system.Physics Procedia, 30, 1079-1089.

[7] Wigginton, M., \& Harris, J. (2002). Intelligent skins. Oxford: Butterworth-Heinemann.

[8] Sacht, H., Bragança, L. \& Almeida, M. (2011). Façade modules for eco-efficient refurbishment of buildings: glazing thermal performance to Guimarães climate. International Conference Sustainability of Constructions - Towards a better built environment, 423-430.

[9] Velikov, K. \& Thun, G. (2012). Responsive Building Envelopes: Characteristics and Evolving Paradigms. In F. Trubiano, ed. esign and Construction of High-Performance Homes: Building Envelopes, Renewable Energies and Integrated Practice. Routledge, 75-92.

[10] Bakker, L.G. et al. (2014). User satisfaction and interaction with automated dynamic facades: A pilot study. Building and Environment, 78, 44-52.

[11] GhaffarianHoseini, A. et al. (2012). Intelligent facades in lowenergy buildings. British Journal of Environment \& Climate Change, 2(4), 437-464.

[12] Loonen, R.C.G. M., Trcka, M. \& Hensen, J.L. M. (2011). Exploring the potential of climate adaptive building shells. In 12th Conference of International Building Performance Simulation Association. 2148-2155

[13] Tzempelikos, A., Athienitis, A.K. \& Karava, P. (2007). Simulation of facade and envelope design options for a new institutional building. Solar Energy, 81(9), 1088-1103.

[14] Bellia, L. et al. (2014). An Overview on Solar Shading Systems for Buildings. Energy Procedia, 62, 309-317.

[15] Kim, G. et al. (2012). Comparative advantage of an exterior shading device in thermal performance for residential buildings. Energy and Buildings, 46, 105-111.

[16] Alzoubi, H. Hendi, Optimizing Lighting, Thermal Performance, And Energy Production of Building Façades Using Automated Blinds And PV Cells, Doctoral dissertation, The University of Michigan, Ann Arbor, USA, 2005.

[17]Tzempelikos, a. et al. (2010). Indoor thermal environmental conditions near glazed facades with shading devices - Part II: Thermal comfort simulation and impact of glazing and shading properties. Building and Environment, 45(11), 2517-2525.
[18]H. Shen, A. Tzempelikos, "Daylighting and energy analysis of private offices with automated interior roller shades", Solar Energy, Vol. 86 (2), pp. 681-704, 2012.

[19]Dilaura, D., Houser, K., Mistrick, R. and Steffy, G. (2012). The lighting handbook, $10^{\text {th }}$ edition, New York: Illuminating Engineering Society.

[20]Murdoch, J. B. (2003). Illuminating engineering: From Edison's lamp to the LED. New York, New York: Visions Communication.

[21]Neill, B.O. (2008). Model-Based Control of Venetian Blinds. Concordia University.

[22]ASHRAE. (2005). Handbook of fundamentals. Atlanta, Georgia: American Society of Heating, Refrigerating, and Air-Conditioning Engineers, Inc.

[23] Bulow-Hube, H., \& Wall, M. (2001). Solar protection in buildings No. TABK--01/3060). Lund, Sweden: Department of Construction and Architecture, Lund University. 